\title{
PHARMACOGNOSTICAL AND PHYSICOCHEMICAL EVALUATION OF THE PLANT LEUCAS ASPERA
}

\author{
KRIPA KG ${ }^{1}$, SANGEETHA $\mathbf{R}^{1}$, CHAMUNDEESWARI $\mathrm{D}^{2 *}$ \\ ${ }^{1}$ Department of Biochemistry, School of Life Sciences, Vels University, Pallavaram, Chennai, Tamil Nadu, India. \\ ${ }^{2}$ Department of Pharmacognosy, Faculty of Pharmacy, Sri Ramachandra Medical University, Porur, Chennai, \\ Tamil Nadu, India. Email: dvchamu@yahoo.co.in \\ Received: 27 June 2016, Revised and Accepted: 04 July 2016
}

\section{ABSTRACT}

Objective: Leucas aspera (Willd.) Linn. is a herbaceous annual distributed throughout India from the Himalayas down to Ceylon. This study was aimed to investigate the pharmacognostical, phytochemical characteristics, and heavy metal content of the aerial parts of $L$. aspera.

Methods: The aerial parts of the plant were subjected to macroscopical and microscopical characterization, followed by physicochemical evaluations using standardized procedures. Atomic absorption spectroscopy (AAS) of the dried plant powder was done to determine the metal and mineral content. Preliminary phytochemical screening and metabolite analysis of the hydroalcoholic extract of $L$. aspera (HAELA) were also performed to analyze the various phytoconstituents.

Results: In this study, the microscopic characteristics of L. aspera were found to be consistent with earlier reports. The total ash value was relatively high $(11.5 \% \mathrm{w} / \mathrm{w})$. Alcohol soluble and water-soluble extractive values were found to be $6.5 \%$ and $9 \%$, respectively. AAS indicated the plant to contain insignificant quantities of heavy metals and considerable amounts of copper, sodium, potassium, and iron. Phytochemical analysis revealed the presence of alkaloids, flavonoids, glycosides, lignins, phenols, saponins, sterols, and tannins in HAELA.

Conclusion: The pharmacognosy - anatomical, physicochemical, heavy metal characteristics, and the preliminary phytochemical studies of the aerial parts of $L$. aspera have revealed the presence of phytoconstituents such as triterpenoids, phenolic compounds, flavonoids, and glycosides; insignificant quantities of heavy metals and significant content of phenolics and tannins in the plant.

Keywords: Leucas aspera, Ash value, Heavy metal content, Atomic absorption spectroscopy.

(C) 2016 The Authors. Published by Innovare Academic Sciences Pvt Ltd. This is an open access article under the CC BY license (http://creativecommons. org/licenses/by/4. 0/) DOI: http://dx.doi.org/10.22159/ajpcr.2016.v9s2.13718

\section{INTRODUCTION}

India has a great wealth of traditional knowledge and wisdom. The classical Indian texts include Rigveda, Atharveda, Charak Samhita, and Sushruta Samhita [1]. Ayurveda is one of the traditional systems of medicine practiced in India and Srilanka and its origin traced back to 6000 BC. Ayurvedic medicines are largely based on herbal and herbomineral preparations and have specific therapeutic principles [2]. Traditional healers used different parts of medicinal plants as medicine. Among the different plant parts, leaves were more frequently used apart from whole plant parts, fruits, stems, roots, flowers, and latex. The methods of preparation fall into four categories, namely plant parts applied as a paste (38\%), juice from fresh plant parts $(20 \%)$, powder from dried plant parts $(20 \%)$, some fresh plant parts $(6 \%)$, and decoction (12\%). Both external applications (for skin diseases, snakebites and wounds) and internal consumption of the preparations were involved in the management of diseases [3].

Today, several medicinal plants and their products are in use, being employed as home remedies, over the counter drugs as well as raw materials for the pharmaceutical industry and they represent a substantial proportion of the global drug market [4]. The objective of producing inexpensive, potent and safer drugs of plant origin can be met to some extent by promoting compound formulations of plant medicines in their natural or semi-processed form (powder or extracts) as used in traditional medicine for common disorders [5]. It becomes extremely important to make an effort toward standardization of the plant material being used as medicine. The process of standardization can be achieved by stepwise pharmacognostic studies. These studies help in identification and authentication of the plant material. Correct identification and quality assurance of the starting materials are an essential prerequisite to ensure reproducible quality of herbal medicine which will contribute to its safety and efficacy. Simple pharmacognostic techniques used in the standardization of plant material include identification of its morphological, anatomical and biochemical characteristics [6].

Leucas aspera (Willd.) Linn. is a herbaceous annual distributed throughout India from the Himalayas down to Ceylon. The plant is used traditionally as an antipyretic and insecticide. Flowers are valued as stimulant, expectorant, aperient, diaphoretic, insecticide, and emmenagogue. Leaves are considered useful in chronic rheumatism, psoriasis, and other chronic skin eruptions. Bruised leaves are applied locally in conditions of snake bites [7]. L. aspera is widely used in countryside as foods and also for the nutritional requirement. The investigation for the phytochemistry of genus Leucas possibly began with Shirangi, 1947 [8] who worked on L. aspera. In plants of the genus Leucas, phenolics are found in abundance. Compounds isolated from $L$. aspera include leucolactone from the root parts, triterpenoid lactone [9],long chain compounds 1-dotriacontanol, 1- hydroxytetratriacontan-4-one, 32-methyltetratriacontane [10], aliphatic ketones [11], and longchain compounds nonatriacontane [12]. Aliphatic ketols, namely 28-hydroxypentatriacontan-7-one, 7-hydroxy-dotriacontan-2- one, and 5-acetoxy-triacontane were isolated from the shoots of L. aspera [11]. Nicotine [13] alpha-farnesene, alpha-thujene, menthol and amyl propionate, isoamyl propionate from leaf and flower volatiles [14] were some among the isolated phytocompounds of L. aspera.

Based on the foregoing, the pharmacognostic investigation, phytochemical analysis and heavy metal quantification of the aerial parts of the plant $L$. aspera have been done with a view to provide pertinent information on its identification, chemical elaboration, and 
pharmacological potential. Findings from this study would be useful as standards for the species as well as a source of reference for further scientific investigation of the species.

\section{METHODS}

\section{Collection of plant material}

The aerial parts of the plant $L$. aspera were collected from Kanchipuram district of Tamil Nadu, India. The plant was taxonomically identified by Dr. N. Jayaraman, Director, National Institute of Herbal Science, Plant Anatomy Research Center, Tambaram, Chennai. Voucher specimen (PARC/2007/362) has been deposited in our college herbarium for future reference.

\section{Plant characterization}

\section{Macroscopical characterization}

Shape, color, taste and odour of leaf and stem were determined and reported.

\section{Microscopical characterization}

Sectioning

The aerial parts of the plants, viz., leaves, stem, flowers, and petals were collected and trimmed. Selected samples were fixed in FAA solution containing formalin $(5 \mathrm{ml})$, acetic acid $(5 \mathrm{ml})$, and $70 \% \mathrm{v} / \mathrm{v}$ ethyl alcohol ( $90 \mathrm{ml})$. After $24 \mathrm{hrs}$ of fixing, the specimens were dehydrated with graded series of tertiary-butyl alcohol (TBA). Infiltration of the specimens was carried by gradual addition of paraffin wax $\left(50-60^{\circ} \mathrm{C}\right)$ until TBA solution attained super saturation. The specimens were casted into paraffin blocks. The paraffin-embedded specimens were sectioned with the help of Rotary Microtome, RMT-30 (Labcon Scientific Instruments, Mumbai). The thickness of the sections was kept between 10 and $12 \mu \mathrm{m}$. The dewaxing of the sections was carried out as per the procedure described by Johanson, 1940 [15]. The sections were stained with phloroglucinol - hydrochloric acid (1:1) and mounted in glycerin.

\section{Photomicrograph}

Microscopic descriptions of selected tissues were supplemented with micrographs. Photographs of different magnifications were taken with Nikon Lab Phot 2 microscopic unit. For normal observations, bright field was used. For the study of crystal, starch grains and lignified cells, polarized light was employed.

\section{Physicochemical evaluations}

Physicochemical parameters of the powdered drug were determined and reported as total ash, water-soluble ash, and acid-insoluble ash values. Alcohol and water-soluble extractive values were determined to find out the amount of water and alcohol soluble components. The moisture content, crude fiber content, and $\mathrm{pH}$ were also determined by standard procedures $[16,17]$.

\section{Determination of pesticide content}

Medicinal plant materials are liable to contain pesticide residues which accumulate from agricultural practices, such as spraying, treatment of soils during cultivation, and administration of fumigants during storage. Since many medicinal preparations of plant origin are taken over a long period of time, limits for pesticide residues should be established following the recommendations of the Food and
Agriculture organization of the United Nations (FAO) and World Health Organization (WHO), both of which have already been established for food and animal feed. Recommendations include the analytical methodology for the assessment of specific pesticide residues. Hence, the pesticide content (organochlorine) was analyzed in the crude drug using TLC.

\section{Metal and mineral content by atomic absorption spectroscopy} Estimation of the elemental concentration in raw drugs and the formulation has gained much importance and has become mandatory for Ayurvedic/Siddha preparation. Hence, in this study, we have estimated the elemental concentration of the dried aerial parts of L. aspera.

\section{Digestion and preparation of sample}

The aerial parts of $L$. aspera were washed with distilled water and dried at $120^{\circ} \mathrm{C}$ in an electric oven till a constant weight was obtained. The dried material was grounded to powder; the powdered drug was weighed into separate flasks and treated with $5 \mathrm{ml} \mathrm{HNO}_{3}$ side by side and $5 \mathrm{ml} \mathrm{HNO}_{3}$ was also added into an empty flask, which served as blank. The flasks were covered with watch glasses and heated to reflux on an electric hot plate at $80^{\circ} \mathrm{C}$ to $100^{\circ} \mathrm{C}$. After heating for $1 \mathrm{hr}$, the contents of flasks were treated with additional $5 \mathrm{ml}$ of $\mathrm{HNO}_{3}$ followed by $2 \mathrm{ml}$ of $30 \% \mathrm{H}_{2} \mathrm{O}_{2}$ followed by heating at gentle reflux till a clear solution was obtained. This was diluted with deionized water and filtered (Whatmann 42) into volumetric flasks and used as sample solutions.

\section{Elemental analysis}

The elemental analysis of digested samples was determined by AAS. The elements such as $\mathrm{Fe}, \mathrm{Cu}, \mathrm{Mn}, \mathrm{Ni}, \mathrm{Zn}, \mathrm{Co}$, and $\mathrm{Pb}$ have been analyzed. In this method, the sample in the form of a homogeneous liquid is introduced into a flame, where thermal and chemical reactions create "free" atoms capable of absorbing, emitting or fluorescing at characteristic wavelengths. The decrease in energy (absorption) is then measured. The absorption is proportional to the concentration of free atoms in the flame, as given by the Beer-Lambert's law. A graph of absorbance against concentration is plotted. The calibration can be performed in the concentration mode in which case the concentration of the sample is read off directly. Calibration of the instrument was repeated periodically during operation. A blank reading was also taken and necessary corrections made during the calculation of the concentration of various elements. The wavelength (nm), flame type atomizer, measurement mode, lamp source, and calibration range (ppm) of different elements have been used, as listed in Table 1.

\section{Preparation of extract}

Shade dried and coarsely powdered aerial parts of L. aspera $(1 \mathrm{~kg})$ was subjected to exhaustive cold maceration in $50 \%$ ethanol for $72 \mathrm{hrs}$ $48 \mathrm{hrs}$, and $24 \mathrm{hrs}$, respectively. The solvent was filtered, distilled under vacuum and dried in a vacuum desiccator to obtain the hydroalcoholic extract of L. aspera (HAELA). This extract was subjected to chemical analysis which includes the preliminary phytochemical screening following standard methods [17].

\section{Primary metabolite analysis}

This involves the quantification of carbohydrates, proteins and lipids in HAELA using standard methods.

Table 1: Instrumental conditions for elemental analysis

\begin{tabular}{llllllll}
\hline Parameter & $\mathbf{F e}$ & $\mathbf{C u}$ & $\mathbf{M n}$ & $\mathbf{N i}$ & $\mathbf{Z n}$ & $\mathbf{C o}$ & $\mathbf{P b}$ \\
\hline Wavelength (nm) & 248.3 & 324.8 & 279.5 & 232.0 & 213.9 & 240.7 & 283.3 \\
Flame composition & A-Ac & A-Ac & A-Ac & A-Ac & A-Ac & A-Ac & A-Ac \\
Atomizer & Standard burner head & & & & & \\
Measurement mode & Absorbance & & & & & \\
Calibration range (ppm) & 0.04-2 & HCL & HCL & HCL & HCL & HCL & HCL \\
Lamp source & HCL-1.3 & $0.016-1$ & $0.006-0.3$ & $0.05-3$ & \\
\hline
\end{tabular}

A-Ac: Air-Acetylene, HCL: Hallow cathode lamp 


\section{Estimation of carbohydrate}

The carbohydrate content of the extract was estimated by the method of Morris et al., 1948 [18]. $1 \mathrm{ml}$ of supernatant (extract hydrolyzed with $2.5 \mathrm{~N} \mathrm{HCl}$, neutralized using solid sodium carbonate, made up to $100 \mathrm{ml}$ and centrifuged to remove supernatent) was pipetted out in triplicates into three test tubes. A tube with $1 \mathrm{ml}$ of water serves as the blank. $4 \mathrm{ml}$ of anthrone reagent was added and heated for $8 \mathrm{~m}$ in water bath and cooled. The green color developed was read at $630 \mathrm{~nm}$. A standard graph of glucose was plotted, from which the carbohydrate content of the extract was determined.

\section{Estimation of total protein}

The protein content of the extract was estimated by the method of Lowry et al., 1953 [19]. $1 \mathrm{ml}$ of the reconstituted extract was pipetted out in triplicates. $4.5 \mathrm{ml}$ of alkaline copper reagent was added, shaken well and allowed to stand for 10 minutes; $0.5 \mathrm{ml}$ of Folin-Ciocalteu reagent was added, shaken well, and incubated at room temperature for 20 minutes. A standard solution containing BSA at a concentration of 20-100 $\mu \mathrm{g}$ and blank were treated in a similar manner. The color developed was measured at $620 \mathrm{~nm}$. The protein content in the tissue homogenate was expressed as $\mathrm{mg} / \mathrm{g}$ extract.

\section{Estimation of total lipids}

Lipids were estimated from the extract according to the method of Folch et al. 1957 [20]. A weighed amount of extract (500 mg) was homogenized with $7 \mathrm{ml}$ of methanol and filtered through a Whatman No.1 filter paper into a conical flask. The residue was scraped and homogenized in $14 \mathrm{ml}$ of chloroform. The residue was once again scraped from the filter paper and ground with $7 \mathrm{ml}$ of chloroformmethanol mixture $(2: 1 \mathrm{v} / \mathrm{v})$ and the resulting filtrate was evaporated to dryness. The weight of the flask with and without the dried lipids was recorded and the difference in weights gave the total lipid content of the extract. Total lipids were expressed as $\mathrm{mg} / \mathrm{g}$ extract.

\section{Secondary metabolite analysis}

Secondary metabolites such as phenols, tannins, vitamins C and E were quantified in all the individual extracts.

\section{Estimation of total phenols}

The total phenolic content of the extract was estimated by the method of Mc Donald et al., 2001 [21]. $1 \mathrm{ml}$ of the extract was taken in triplicates, and the volume was made up to $1 \mathrm{ml}$ with methanol. $1 \mathrm{ml}$ of water serves as the blank. To this, $5 \mathrm{ml}$ of Folin's phenol reagent was added followed by $4 \mathrm{ml}$ of $7.5 \%$ sodium carbonate and kept at room temperature for 1.5 hrs. The intensity of blue color formed was read at $765 \mathrm{~nm}$. A standard graph of gallic acid was plotted, from which the phenol content of the extract was determined.

\section{Estimation of tannins}

The tannin content of the extract was estimated by the method of Mc Donald et al., 2001 [21]. $1 \mathrm{ml}$ of the extract was taken in triplicates, and the volume was made up to $1 \mathrm{ml}$ with distilled water. $1 \mathrm{ml}$ of water serves as the blank. To this $0.5 \mathrm{ml}$ of Folin's phenol reagent was added followed by $5 \mathrm{ml}$ of $3.5 \%$ sodium carbonate and kept at room temperature for 5 minutes. The intensity of blue color formed was read at $640 \mathrm{~nm}$. A standard graph was plotted, from which the tannin content of the extract was determined.

\section{Estimation of vitamin $C$}

The vitamin C content of the extract was estimated by the method of Roe et al., 1943 [22]. $2 \mathrm{ml}$ of sample extracts were taken in two test tubes. The volume was made up to $3 \mathrm{ml}$ with methanol: Water. $3 \mathrm{ml}$ of methanol: Water serves as the blank. To this $0.2 \mathrm{ml}$ DTC reagent was added and mixed well and the tubes were incubated at $37^{\circ} \mathrm{C}$ for $3 \mathrm{hrs} .1 .5 \mathrm{ml}$ of $85 \% \mathrm{H}_{2} \mathrm{SO}_{4}$ was added and kept at room temperature for 30 minutes. Orange red color complex was formed, the intensity of which was read at $520 \mathrm{~nm}$. A standard graph of ascorbic acid was plotted, from which the vitamin $\mathrm{C}$ content of the extract was determined.

\section{Estimation of vitamin $E$}

The vitamin E content of the extract was estimated by the method of Baker et al., 1980 [23]. Three stoppered centrifuge tubes with $1.5 \mathrm{ml}$ each of extracts, standard, and water (blank) were taken. To the test and blank, $1.5 \mathrm{ml}$ of ethanol was added and to the standard and $1.5 \mathrm{ml}$ of water was added. This is followed by $1.5 \mathrm{ml}$ of xylene to all the tubes, tubes were stoppered, contents mixed well, and centrifuged. Transfer $1 \mathrm{ml}$ of the bottom xylene layer into other stoppered tubes taking care not to include any ethanol or protein. Add $1 \mathrm{ml} \alpha, \alpha$ dipyridyl reagent to each tube, stopper, and mix. Pipette out $1.5 \mathrm{ml}$ of the mixture into colorimeter cuvettes and read the extinction of test and standard against the blank at $460 \mathrm{~nm}$. Now, beginning with the blank, add $0.33 \mathrm{ml}$ ferric chloride solution, mix, and after exactly 1.5 minutes, test and standard were read against the blank at $520 \mathrm{~nm}$.

Tocopherol $(\mathrm{mg} / \mathrm{L})=\frac{\begin{array}{l}\text { Reading of unknown at } 520 \mathrm{~nm}- \\ \text { Reading at } 460 \mathrm{~nm} \times 0.29) \times 10\end{array}}{\text { Reading of standard at } 520 \mathrm{~nm}}$
The vitamin E content of the extract was expressed as $\mathrm{mg} \%$.

\section{RESULTS AND DISCUSSION}

The WHO has long recognized that traditional medicinal plants could be useful in an integrated health care delivery system of a country. Medicinal plants are starting material for any herbal preparation such as herbal medicines, herbal teas, and herbal oil. In developing countries, large numbers of the population are unable to afford pharmaceutical drugs, and they continue to use their own systems of indigenous medicine that are mainly plant based. These preparations are being used worldwide due to their therapeutic potential and as they are considered to be safe as compared to allopathic medicines. Hence, there is a great need to harness scientific and clinical research to investigate the quality, safety and efficacy of these herbal therapies [24]. These plants must not be dangerous, be effective and the preparations should not be adulterated or made harmful by parasites and microorganisms [25]. Thus for medicinal plants to be used alongside modern medicine, careful phytochemical, pharmacological and toxicological standardization of the chosen plants must be instituted so that dosage levels can be described in an informed way [26]. It was in this vein that the phytochemical, physicochemical and pharmacognostical investigations of the medicinal plant $L$. aspera were pursued.

\section{Macroscopic evaluation of $L$. aspera}

L. aspera is an annual, branched, herb which erects to a height of $15-60 \mathrm{~cm}$ with stout and hispid acutely quadrangular stem and branches. Leaves are subsessile or shortly petiolate, linear or linearlylanceolate, obtuse, pubescent up to $8.0 \mathrm{~cm}$ long and $1.25 \mathrm{~cm}$ broad, with entire or crenate margin; petiole is about $2.5-6 \mathrm{~mm}$ long; flowers white, sessile small, in dense terminal or axillary whorls; bracts $6 \mathrm{~mm}$ long, linear, acute, bristle-tipped, ciliate with long slender hairs; calyx variable, tubular, 8-13 $\mathrm{mm}$ long; tube curved, contracted above the nutlets, the lower half usually glabrous and membranous, the upper half ribbed and hispid; mouth small, very oblique, not villous, the upper part produced forward; teeth small, triangular, bristle-tipped, ciliate, the upper tooth being the largest. Corolla was $1 \mathrm{~cm}$ long; tube $5 \mathrm{~mm}$ long and pubescent above, annulate in the middle; upper lip $3 \mathrm{~mm}$ long, densely white-woolly; lower lip about twice as long, the middle lobe obviate, rounded, the lateral lobes small, subacute. Fruit nutlets are $2.5 \mathrm{~mm}$ long, oblong, brown, smooth, inner face angular, and outer face rounded (Fig. 1).

\section{Microscopic evaluation of $L$. aspera}

Stem: Diagrammatic TS of young stem is quadrangular in outline with four distinct collenchymatous ridges, covered with hairs. It shows a narrow cortex and a ring of vascular tissue encircling the wide stele. 
Detailed TS shows an epidermis covered with thick cuticle, traversed occasionally with stomata and bears simple, multicellular (three to fourcelled) uniseriate lignified trichomes and sessile, glandular trichomes with multicellular head; narrow parenchymatous cortex; stellar region consisting of a ring of vascular bundles connected with inter-fascicular sclerenchymatous band; very narrow parenchymatous phloem, and radially arranged xylem tissue. In old stem, trichomes are few, phloem tissue is wide and found on either side of the wide xylem band; pith is parenchymatous, wide and embedded with acicular crystals.

Leaf: Dorsiventral, the midrib consists of thin layer of epidermis with 2-3 layers of collenchyma followed by cortex. Shape is hemispherical with radiating xylem and 1-2 seriate medullary ray surrounded by narrow phloem. Uniseriate multicellular covering trichomes (CT) with sharp end; uniseriate multicellular glandular trichome with unicellular head on both sides are also seen. The lamina consists of thin layer of epidermis with stomata on both sides and two layers of palisade cells with vascular elements in the mesophyll cortex. Plenty of CT and scarce glandular trichomes are also seen.

Root: Slender with thin layer of cork followed by 7-8 layers of cortex narrow phloem, distinct cambium, wide secondary xylem, radiating 2-3 seriate ray cells, primary xylem is narrow with radiating xylem vessels. TS of root under polarized light shows druces scattered in the wide cortex. The microscopic characteristics of $L$. aspera has thus been described, and the characteristics were consistent with the earlier reports on this plant [27]. (Fig 2)

\section{Heavy metal content of $L$ aspera}

The presence of heavy metals in various herbal ingredients and products has been reported by several researchers [28]. These reports

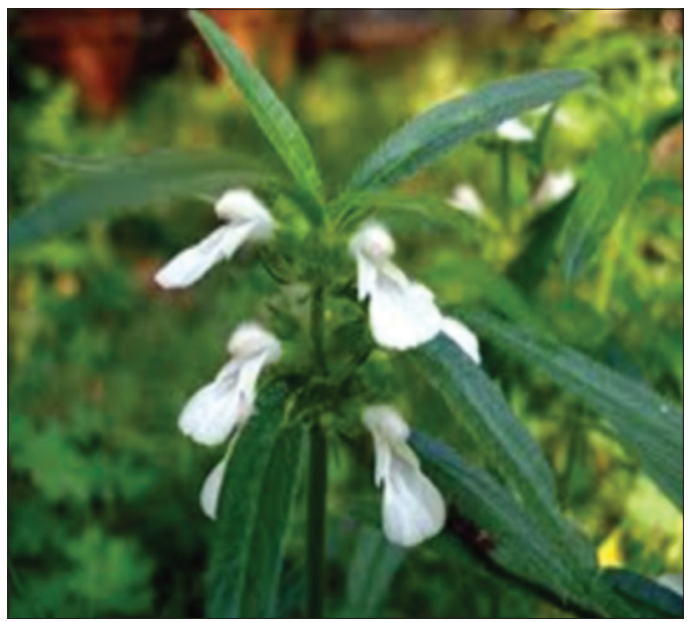

Fig. 1: Macroscopic features of Leucas aspera throw light on the fact that medicinal plants which are considered harmless and are used as starting material for any herbal product may also contain toxic metals. WHO has laid emphasis on the need of quality assurance of these herbal preparations for heavy metals such as lead, cadmium, chromium, nickel, arsenic, and mercury. In this study, attempts have been made to study the presence of lead, cadmium, chromium, nickel, arsenic, and lead in L. aspera. Lead, cadmium, chromium, nickel, arsenic, and mercury are the most common toxic metals that have become a matter of concern due to the reports of their contamination in various herbal preparations and herbal ingredients.

Lead is known to cause neurological disorders, anemia, kidney damage, miscarriage, lower sperm count, and hepatotoxicity when in high concentrations. Acute or chronic exposure of cadmium causes respiratory distress, lung and breast cancers, hemorrhagic injuries, anemia, and cardiovascular disorders. Arsenic is reported to cause hypertension, peripheral arteriosclerosis, skin diseases, and neurotoxicity whereas mercury causes neurological disorders, paralysis, digestive tract inflammation, uremia, acrodynia and immunotoxicity $[29,30]$. Nickel has been reported to cause contact dermatitis, nasal, sinus and lung cancers, kidney disorders, chronic bronchitis, acute respiratory distress syndrome, and pulmonary fibrosis. Chromium is known to cause nephrotoxicity, nasal and lung ulcers, skin ulcers, hypersensitivity reactions and "chrome holes" of the skin as reported by Naithani et al., 2010 [28]. This study has highlighted the fact that L. aspera contains insignificant quantities of heavy metals and considerable amounts of copper, sodium, potassium, and iron (Table 2).

Pesticides are single substances or mixtures (organochlorine, organophosphorus, carbamate, and tria-zinc compounds) used to eliminate undesirable vegetable and animal life in agricultural and urban ecosystems. The abusive and disordered employment of pesticides has caused a series of problems of an ecological and public health nature and hence their presence in herbal preparations should be monitored. This study confirmed the absence of pesticides and aflatoxins.

Physicochemical and phytochemical constituents of $L$. aspera This study on physicochemical characteristics and preliminary phytochemical screening provides useful information which may help in authenticating the genuine plant along with the nature of phytoconstituents present in it [31]. There is a need to evaluate herbal treatments by clinical trials using currently accepted protocols. Results for physicochemical parameters are given in Table 3. The total ash value was relatively high $(11.5 \% \mathrm{w} / \mathrm{w})$ which may be due to high content of phosphates, carbonates, silicates, and silica. The ash value is an important quantitative tool used to determine the authenticity and purity of drug. Percent weight loss on drying or moisture content was found to be $8.75 \%$. The less value of moisture content could prevent bacterial, fungal, or yeast growth. Crude fiber content of the plant material was found to be $2.5 \% \mathrm{w} / \mathrm{w}$. Determination of crude fiber is useful in distinguishing between similar drugs and also in the detection

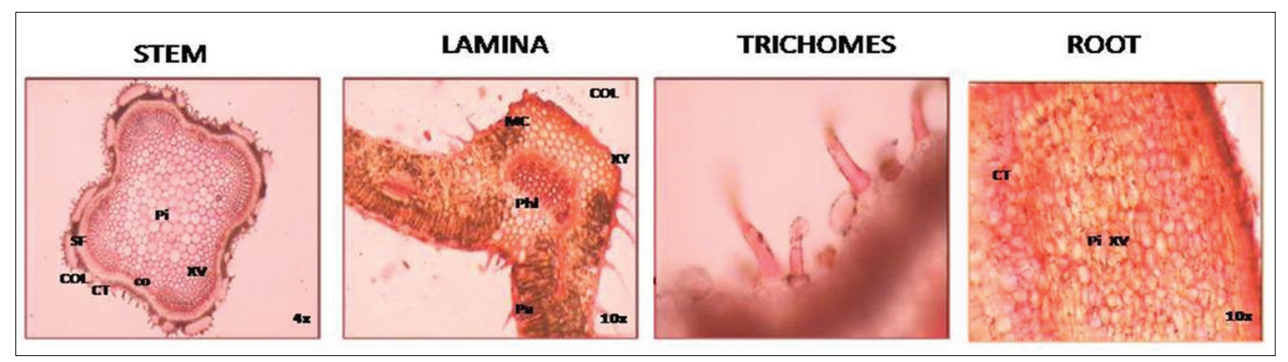

Fig. 2: Microscopical characterization of Leucas aspera. STEM: C.S of stem $(\times 4)$ showing full stem; pockets of collenchyma as ridges interspaced by scleroidal fibers. Pith region and covering trichomes are seen in the epidermal layer. LAMINA: T.S of mid rib showing closed collateral vascular bundles with covering hairy trichomes, 2-4 cell wide, few glandular trichomes; mesophyll cortex; lamina region shows a single layer of palisade cells beneath epidermal cells. Vascular elements are seen $(\times 10)$. Trichomes: Enlarged covering trichomes in the collenchyma region $(\times 45)$. ROOT: T.S of root showing xylem vessels, medullary rays and cortex covering trichomes followed by the cork region $(\times 10)$ 
Table 2: Heavy metal analysis of $L$. aspera

\begin{tabular}{lll}
\hline S.N & Elements & Quantity \\
\hline 1 & Calcium & $18.8 \mathrm{ppm}$ \\
2 & Sodium & $4.83 \mathrm{ppm}$ \\
3 & Potassium & $23.4 \mathrm{ppm}$ \\
4 & Iron & $2.742 \mathrm{ppm}$ \\
5 & Copper & $0.449 \mathrm{ppm}$ \\
6 & Zinc & $0.478 \mathrm{ppm}$ \\
7 & Chromium & $1.326 \mathrm{ppm}$ \\
8 & Manganese & $0.646 \mathrm{ppm}$ \\
9 & Lead & $0.008 \mathrm{ppm}$ \\
10 & Arsenic & $0.025 \mathrm{ppb}$ \\
11 & Cobalt & $194.5 \mathrm{ppb}$ \\
12 & Mercury & $201.37 \mathrm{ppb}$ \\
\hline
\end{tabular}

L. aspera: Leucas aspera

Table 3: Ash analysis of aerial parts of L. aspera

\begin{tabular}{ll}
\hline Parameters & Values $(\% \mathbf{w} / \mathbf{w})$ \\
\hline Total Ash & $11.5 \pm 0.9$ \\
Water-insoluble Ash & $7.5 \pm 0.6$ \\
Acid-insoluble Ash & $1.8 \pm 0.1$ \\
Loss on drying & $10.5 \pm 1.1$ \\
\hline
\end{tabular}

Data are represented as mean \pm SEM, $n=3$, L. aspera: Leucas aspera,

SEM: Standard error of mean

Table 4: Extractive values of extracts of $L$. aspera

\begin{tabular}{ll}
\hline Parameters & Values $(\% \mathbf{w} / \mathbf{w})$ \\
\hline Water soluble extractive & $9.0 \pm 0.8$ \\
Alcohol soluble extractive & $6.5 \pm 0.5$ \\
Hydro-alcoholic & $9.5 \pm 0.7$ \\
Crude fibre content & $2.5 \pm 0.1$ \\
\hline
\end{tabular}

Data are represented as Mean $\pm \mathrm{SEM}, \mathrm{n}=3$, L. aspera: Leucas aspera, SEM: Standard error of mean

of adulteration. It also helps to remove the more resistant parts of plant organs which can be used for microscopic examination. Alcohol soluble and water-soluble extractive values were found to be $6.5 \%$ and $9 \%$, respectively. The percent yields of different extracts are given in Table 4 .

The curative properties of medicinal plants are perhaps due to the presence of various secondary metabolites such as alkaloids, flavonoids, glycosides, phenols, saponins, and sterols. The successive extracts of aerial parts of $L$. aspera have revealed the presence of alkaloids, flavonoids, glycosides, lignins, phenols, saponins, sterols, and tannins (Table 5). Thus, the preliminary screening tests may be useful in the detection of the bioactive principles and subsequently may lead to the drug discovery and development. Further, these tests facilitate their quantitative estimation and qualitative separation of pharmacologically active chemical compounds [32].

The results of the phytochemical analysis of the investigated HAELA have indicated the presence of different types of active constituents inclusive of tannins (29 $\mathrm{mg} \%$ ) and phenolics (4.3 $\mathrm{mg} \%$ ) apart from carbohydrates and proteins (Table 6). Condensed tannins are polyphenolic natural products composed of flavan-3-ol sub-units linked mainly through C4-C8 (or C4-C6) bonds which are significant plant secondary metabolites. Tannins in vascular plants occur as two types, condensed or hydrolysable tannins. Tannins have received considerable attention in the fields of nutrition, health and medicine, largely due to their physiological activity such as antioxidant activity, anti-microbial effects, and anti-inflammatory properties. Tannins are powerful antioxidants often characterized by reducing power and free radical scavenging activities [33]. In addition, the astringent taste of L. aspera may be attributed to the high concentrations of tannins which prevent it from herbivory.
Table 5: Preliminary phytochemical screening of HAELA

\begin{tabular}{lll}
\hline S.N & Phytoconstituents & HAELA \\
\hline 1. & Steroids & - \\
2. & Phenolic compounds & ++ \\
3. & Reducing sugars & + \\
4. & Flavonoids & ++ \\
5. & Glycosides & + \\
6. & Saponins & + \\
7. & Triterpenoids & + \\
8. & Alkaloids & + \\
9. & Anthraquinones & + \\
10. & Tannins & ++ \\
11. & Quinones & - \\
12. & Coumarins & + \\
\hline
\end{tabular}

HAELA: Hydroalcoholic extract of L. aspera, +: trace, ++: Moderate, +++ : Significant. L. aspera: Leucas aspera

Table 6: Metabolite analysis of HAELA

\begin{tabular}{ll}
\hline Metabolites & $\mathbf{m g} \% \mathbf{( w / w )}$ \\
\hline Total carbohydrates & $12.3 \pm 0.9$ \\
Primary metabolites & $7 \pm 0.6$ \\
$\quad$ Total proteins & $0.2 \pm 0.03$ \\
Total lipids & $4.3 \pm 0.2$ \\
Phenols & \\
Secondary metabolites & $29 \pm 1.5$ \\
$\quad$ Tannins & $5 \pm 0.3$ \\
Vitamin C & $1.7 \pm 0.2$ \\
$\quad$ Vitamin E & \\
\hline Data are represented as Mean \pm SEM, $\mathrm{n}=3$, HAELA: Hydroalcoholic extracts of \\
L. aspera. L. aspera: Leucas aspera, SEM:Standard error of mean
\end{tabular}

\section{CONCLUSION}

The pharmacognosy - anatomical, physicochemical, heavy metal characteristics, and the preliminary phytochemical studies of the aerial parts of L. aspera have revealed the presence of phytoconstituents such as triterpenoids, phenolic compounds, flavonoids, and glycosides; insignificant quantities of heavy metals and significant content of phenolics and tannins in the plant.

\section{REFERENCES}

1. Kamboj V. Herbal medicine. Curr Sci 2000;78(1):35-9

2. Patwardhan B, Hopper B. Ayurvedic and future drug development. J Altern Complement Med 1992;19:9-10.

3. Muthu C, Ayyanar M, Raja N, Ignacimuthu S. Medicinal plants used by traditional healers in Kanchipuram district of Tamil Nadu, India. J Ethnobiol Ethnomed 2006;2:43-7.

4. Mulla SK, Swamy P. Preliminary pharmacognostical and phytochemical evaluation of Portulaca quadrifida Linn. Int J PharmTech Res 2010;2:1699-702.

5. Gupta SS. Prospects and perspectives of natural plants products in Medicine. Indian J Pharmacol 1994;26:1-12.

6. Thomas S, Patil DA, Patil AG, Chandra N. Pharmacognostic evaluation and physicochemical analysis of averrhoa carambola L. Fruit. J Herb Med Toxicol 2008;2:51-4.

7. Kirtikar KR, Basu BD. Indian Medicinal Plants. $2^{\text {nd }}$ ed. Dehradun: Lalit Mohan Basu; 1991.

8. Shirangi AM. Studies on Leucas aspera. Indian J Pharma 1947;159.

9. Pradhan BP, Chakraborthy DK, Subba GC. A triterpenoid lactone from Leucas aspera. Phytochemistry 1991;29:1693-5.

10. Mishra TN, Singh RS, Pandey HS, Singh S. Long chain compounds from Leucas aspera. Phytochemistry 1992;31:1809-10.

11. Mishra TN, Singh RS, Prasad C, Singh S. Two aliphatic ketols from Leucas aspera. Phytochemistry 1993;32:199-201.

12. Mishra TN, Singh RS, Pandey HS, Singh S. A novel phenolic compound from Leucas aspera. Indian J Chem 1995;34:1108-10.

13. Mangathayaru K, Thirumurugan D, Patel PS, Pratap DV, David DJ, Karthikeyan J. Isolation and identification of nicotine from Leucas aspera (Willd) link. Indian J Pharm Sci 2006b;68:88-90.

14. Mangathayaru K, Ghosh A, Ranjan R, Kaushik VV. Volatile constituents 
of Leucas aspera (Willd.) Link. J Essent Oil Res 2006a;18:104-5.

15. Johanson DA. Plant Microtechniques. New York: McGraw Hill Book Co.; 1940. p. 523.

16. Sandeep G, Dheeraj A, Deenanath J, Kumar SN, Bharti AS Pharmacognostic Standardization, physico and phytochemical evaluation of aerial parts of Mentha arvensis linn. International J Pharma Sci Drug Res 2010;2:261-4.

17. Trease GE, Evans WC. Textbook of Pharmacology. $12^{\text {th }}$ ed. London: Tindale; 1983.

18. Morris DL. Quantitative determination of carbohydrate with Dreywood's anthrone reagent. Science 1948;107:254-5.

19. Lowry OH, Rosebrough NJ, Farr AL, Randall RI. Protein measurement with Folin Phenol reagent. J Biol Chem 1951;193(1):265-75.

20. Folch J, Lees M, Sloane Stanley GH. A simple method for the isolation and purification of total lipids from animal tissues. J Biol Chem 1957;226(1):497-09.

21. McDonald S, Prenzler PD, Autolovich M, Robards K. Phenolic content and antioxidant activity of olive extracts. Food Chem 2001;73(1):73-84

22. Roe JH, Kuether CA. The determination of ascorbic acid in whole blood and urine through the 2, 4-dinitrophenylhydrazine derivative of dehydroascorbic acid. J Biol Chem 1943;147:399-407.

23. Baker H, Frank O, De Angelis B, Feingold S. Plasma tocopherol in man at various times after ingesting free or acetylated tocopherol. Nutr Rep Int 1980;21:531-6.

24. Phillipson JD. Phytochemical evaluation of some Kenyan medicinal plants. Phytochemistry 2001;56:237-43.

25. WHO (World Health Organization). Quality Control Methods for
Medicinal Plant Materials. Geneva, Switzerland: World Health Organization; 1998

26. Midiwo JO, Yenesew A, Juma BF, Omosa KL, Omosa IL, Mutisya D $11^{\text {th }}$ NAPRECA Symposium Book of Proceedings. Antananarivo: Madagascar; 2006. p. 9-19.

27. Rai V, Agarwaal M, Agnihotri AK, Khatoon S, Rawat AK, Mehrotra S. Pharmacognostical evaluation of Leucas aspera Link. Nat Prod Sci 2005;11:109-14.

28. Naithani V, Pathak N, Chaudhary M. Evaluation of heavy metals in two major ingredients of ampucare. Int J Pharm Sci Drug Res 2010;2:137-41.

29. Ghosh A, Chakrabarti P, Roy P, Bhadury S, Nag T, Sarkar S. Bioremediation of heavy metals from neem (Azadirachta indica) leaf extract by chelation with dithizone (a prospective and effective method for pharmaceutical industry). Asian J Pharm Clin Res 2009;2:87-92.

30. Nkansah MA, Amoako CO. Heavy metal content of some common spices available in markets in the Kumasi metropolis of Ghana. Am J Sci Ind Res 2010;1:158-63.

31. Devi P, Meera R, Muthumani P, Kameswari B, Badmanaban R. PhytoPhysico chemical evaluation and Antioxidant activities of leaves of Naphellium lappaceum. J Pharm Sci Res 2009;1:117-22.

32. Mallikharjuna PB, Rajanna LN, Seetharam YN, Sharanabasappa GK Phytochemical studies of Strychnos potatorum L.f. - A medicinal plant. E-J Chem 2007;4(4):510-8.

33. Zhang LL, Lin YM. HPLC, NMR and MALDI-TOF MS analysis of condensed tannins from Lithocarpus glaber leaves with potent free radical scavenging activity. Molecules 2008;13:2986-97. 